\title{
Central and Eastern Europe paleoscience symposium: From local to global
}

\author{
Marcel Mîndrescu $u^{1,2}$ and lonela Grădinaru $u^{1,2}$ \\ Cluj-Napoca, Romania, 23-24 May 2016
}

\begin{abstract}
The projected climatic changes and increasing anthropogenic pressure by the end of this century are generating global concerns about the potential impacts on environment and society. Most environments are currently shaped by the interactions between the changing climate and human disturbances, therefore understanding environmental dynamics cannot be achieved without considering both climatic and anthropogenic drivers (Dearing et al. 2015).
\end{abstract}

An increasing number and diversity of paleoclimatic studies spanning the Holocene have indicated that climate underwent complex developments that rarely followed larger spatial scale patterns (e.g. Wenniger et al. 2009). However, at continental levels the cohesion of climatic shifts was documented to increase, as more and more archives, unevenly distributed across Europe, contributed to the state of knowledge.

As part of the continental scale, Central and Eastern (CE) Europe has only recently entered the continental ensemble of paleoclimatic reconstructions, despite its significant potential given by the geographic location, at the junction of major air masses (i.e. Atlantic, Mediterranean and Siberian) which shaped a landscape with strong climatic regimes, and landform heterogeneity. Moreover, in this region lies the last orographic barrier of Europe, the Carpathians, beyond which Eastern climatic influences are most strongly felt, thus converting the Carpathian range into an area of climatic transition (Fig. 1).

The location and layout of the Carpathians, which interfere to a significant degree with the latitudinal advection of air masses (Baltic to Mediterranean and vice versa: from sea to sea), and, more prominently, with the longitudinal circulation (Atlantic to Ural and vice versa), have been a key factor for understanding past and current climate changes in the region (Fig. 1). The Carpathian influences include both long-ranging effects (decreasing air humidity and precipitation eastward, detaining drier, more continental Eastern air masses) and local effects (the Carpathians breezes, thermal inversions, foehn winds, etc.), which factor into the climatic heterogeneity of the region.

Although the climate of the past, especially for the last millennium, and its relationship to human activities has been extensively studied, there remains a paucity

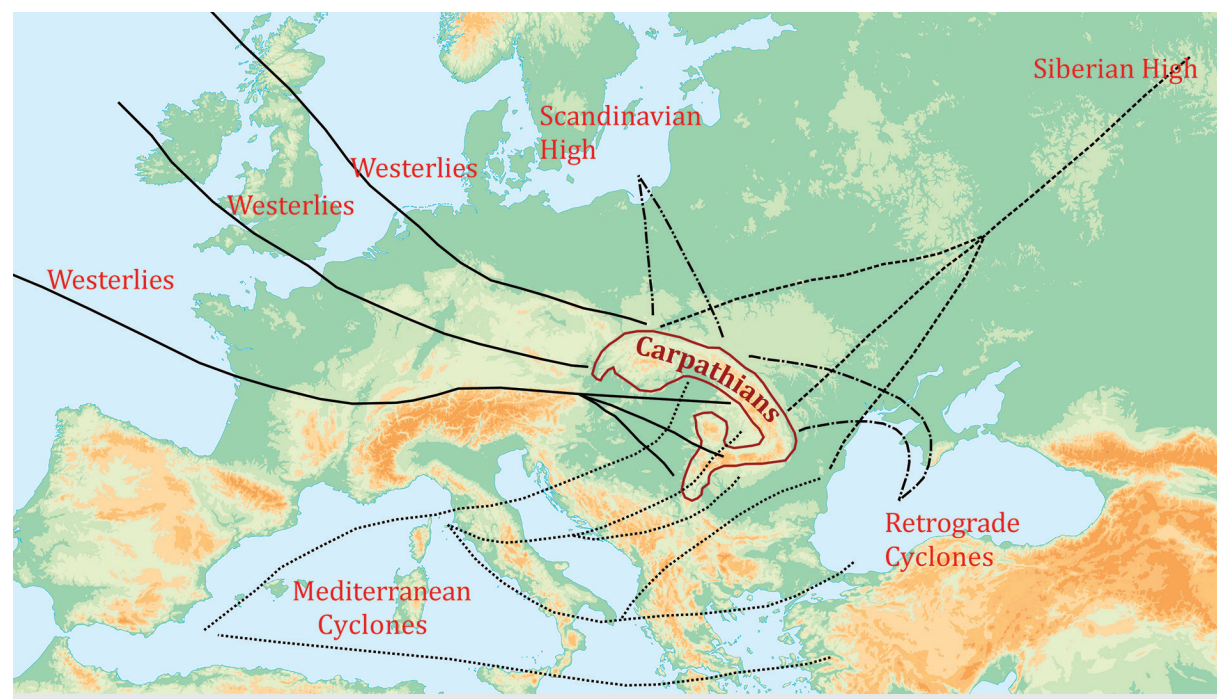

Figure 1: Relief map of Europe with the location of the Carpathian range (dark red contour line) and schematic representation of the main atmospheric circulation patterns in the region.

of paleoenvironmental information over significant geographical areas, including CE Europe (Florescu et al. 2017). Therefore in order to support paleoenvironmental research conducted in the region by local and foreign scientists, a PAGES-supported conference was organized in 2016, focusing on climate changes in CE Europe and their implications at various scales: Central and Eastern Europe Paleoscience Symposium: From Local to Global - CEEP 2016. The event, attended by local and foreign researchers, senior and young scientists, stakeholders, policy makers and natural parks officers, addressed paleoclimatological and paleoenvironmental research and coincided with PAGES' annual Scientific Steering Committee (SSC) meeting.

The symposium comprised six sessions focused on: Coordinated global change research; The climate system from a paleo perspective; Landscapes, biota and biosphere interactions; Interactions between humans and the environment; Outreach - communicating past global change research to stakeholders; and Thresholds and extremes as examples of PAGES' integrative activities. The event was attended by 120 participants, of which 70 presented their contributions (39 oral presentations and 31 posters), from 22 countries. The abstracts for all the contribu tions were published in a special volume of Georeview Journal (http://georeview.ro/ojs/ index.php/revista/issue/view/24). Some of the contributions presented at the symposium will also be published in a special issue
"European Paleoscience" of Quaternary International (in prep.).

The meeting was held between May 20 and 26, which included PAGES' SSC meeting and a field trip which took participants to the Apuseni Mountains. The main site of interest there was the Scărişoara Ice Cave (700 $\mathrm{m}$ long, $105 \mathrm{~m}$ deep, $1165 \mathrm{~m}$ asl), famous for the world's largest $\left(100000 \mathrm{~m}^{3}, 22.5 \mathrm{~m}\right.$ thick) and one of the oldest (ca. 10.500 BP) cave ice deposits (Racoviţă and Onac 2000). The duration and tone of the meeting were favorable for scientific interaction and the exchange of ideas, as well as acquainting participants with Romania's natural environment and traditions, which could perhaps be listed among the greatest achievements of this conference.

\section{AFFILIATIONS}

'Department of Geography, University of Suceava, Romania

${ }^{2}$ Geoconcept Association of Applied Geography, Suceava, Romania

CONTACT

Marcel Mîndrescu: marcel.mindrescu@gmail.com

\section{REFERENCES}

Dearing JA et al. (2015) Anthropocene Rev 2: 1-27

Florescu G et al. (2017) Palaeogeogr Palaeoclim Palaeoecol 473: 26-40

Racoviţă G, Onac BP (2000) Scărişoara Glacier Cave. Monographic Study. Editura Carpatica, 140 pp

Weninger B et al. (2009) Docu praehist 36: 7-59 